\title{
Analysis of Functional Suitability and Usability in Sales Order Procedure to Determine Management Information System Quality
}

Analisis Fungsionalitas dam Usability Sistem Informasi Manajemen Sales Order Untuk Menentukan Kualitas Sistem

Received:

7 January 2021

Revised:

17 July 2021

Published:

8 August 2021

\author{
${ }^{1 * \text { Sri Ariyani, }}{ }^{2}$ Made Sudarma, ${ }^{3}$ Putu Aryasuta Wicaksana \\ 1,2,3 Departement of Electrical and Computer Engineering, Post \\ Graduate Program, Udayana University \\ ${ }^{1,2}$ Denpasar, Indonesia \\ E-mail: ${ }^{1}$ sriariyani@unud.ac.id, ${ }^{2}$ msudarma@unud.ac.id, \\ ${ }^{3}$ aryasutawicaksana@gmail.com
}

*Corresponding Author

\begin{abstract}
In the development of information systems, it is very important to pay attention to the quality of the system which can be reviewed through aspects of usability for its users and following the needs and specifications of its users. This study will analyze the quality of the sales order management information system based on two characteristics of the ISO 25010 quality standard system, namely functional suitability and usability. The functional suitability test was carried out by the BlackBox testing method to test three sub-characteristics of functional suitability that are functional completeness, functional correctness, and functional appropriateness. Usability tests use a use questionnaire which is divided into four criteria that are usefulness, ease of use, ease of learning, and satisfaction. In testing the suitability of functionality involving 5 respondents and 17 respondents in usability testing. The results of this study indicate that the sales order management system fulfills two characteristics of information system quality that are functional suitability and usability. Where all the features designed are by the successful features, and the usability characteristics are $85.45 \%$ which indicates that the system is very feasible to implement.
\end{abstract}

Keyword - Information System Quality, ISO 25010, Functional Suitability, Usability

\begin{abstract}
Abstrak - Dalam pengembangan sistem informasi yang sangat penting memperhatikan kualitas sistem yang dapat ditinjau melalui aspek kegunaan bagi penggunanya dan mengikuti kebutuhan serta spesifikasi penggunanya. Penelitian ini akan menganalisis kualitas sistem informasi manajemen pesanan penjualan berdasarkan dua karakteristik sistem standar mutu ISO 25010, yaitu kesesuaian fungsional dan kegunaan. Uji kesesuaian fungsional dilakukan dengan metode pengujian blackbox untuk menguji tiga sub karakteristik kesesuaian fungsional yaitu kelengkapan fungsional, ketelitian fungsional, dan kesesuaian fungsional. Uji kegunaan menggunakan Use Quisionnaire yang dibagi menjadi empat kriteria yaitu kegunaan, kemudahan penggunaan, kemudahan belajar, dan kepuasan. Di dalam melakukan pengujian kesesuaian fungsionalitas melibatkan 5 responden dan 17 responden pada pengujian kegunaan. Hasil penelitian ini menunjukkan bahwa sistem manajemen pesanan penjualan memenuhi dua karakteristik kualitas sistem informasi yaitu kesesuaian fungsional dan kegunaan. Dimana semua fitur yang dirancang sudah sesuai dengan fitur yang berhasil, dan karakteristik usability $85.45 \%$ yang menunjukkan bahwa sistem sangat layak untuk diimplementasikan.
\end{abstract}

Kata Kunci-Kualitas Sistem Informasi, ISO 25010, Functional Suitability, Usability 


\section{INTRODUCTION}

Information systems are a series of components that can be in the form of people, procedures, data, and technology used to carry out a process in decision making to support the success of each organization in achieving each goal [1]. In developing information systems, quality is an important factor that must be considered. The quality of information systems is how a system can provide useful products and services for its users. The quality of information systems is a process by which the system is effectively implemented and able to meet the needs of its users [2]. The quality of the information system will depend on user satisfaction [3].

At PT. Bali Yoni Saguna is currently developing an information system to manage sales order procedures. A sales order is an internal procedure performed for the initialization of a project or sale. The information system being built is named BASSO (Baliyoni Saguna Sales Order). Where the information system will be used by several divisions such as the marketing division, sales admin, warehouse, and shipping division. The problem at this time is, it is not known whether the system being developed currently meets the standards and whether the system has been able to meet the needs of its users in functionality and whether the BASSO information system is feasible to implement. So, to be able to find out a quality information system and can meet the needs of its users, an evaluation is needed [4], because an information system must be able to display information appropriately to facilitate the work of its users or can assist in making a decision [5]. And to find out the suitability of the information system and its use in determining the quality of the system, it can be done by measuring the suitability of the features of the system and the extent to which a system can be used by its users, where when compared with the quality characteristics of the ISO 25010 standard system, these measurements are based on two characteristics, namely functional suitability and usability [6].

Several standards can be used to test the quality of information systems such as McCall, Boehm, FRUPS, Dromey, Brtoa, ISO 9126, and ISO 25010. And from those various standards, ISO 25010 is an international standard in information system testing [7].

ISO 25010 is a part of the series of standards ISO/IEC 25000, ISO/IEC 2501n divided into 2 divisions namely ISO/IEC 25010 - System and software quality models and ISO/IEC 25012 Data Quality model. ISO25000 series as a new generation of International Organization for Standardization requirements document connected with software standardization and its quality evaluation[8]. ISO 25010 is an international standard developed to replace ISO 9126 which is based on developments in ICT (Information and Communication Technology), such as microprocessor developments, memory developments, display developments, and storage developments. [9]. ISO 25010 Quality Model Division is the international standard that forms 
INTENSIF, Vol.5 No.2 August 2021

ISSN: 2580-409X (Print) / 2549-6824 (Online)

DOI: https://doi.org/10.29407/intensif.v5i2.15537

this division presents detailed quality models for computer systems and software products, quality in use, and data. ISO 25010 consists of eight sub characteristics, two of which are functional suitability and usability [10]. Functional suitability is one of the quality factor which measured by observing the correlation between function and functional suitability, the functional suitability checks if the product or system provides a function that meets all the stated or implicit needs when used under specific condition [11], and usability test is one way of ensuring that interactive systems are adapted to the users, their tasks and that there are no negative outcomes of their usage [12].

This study refers to previous studies on functional suitability and usability testing. First is functional suitability testing on the implementation of Balinese script learning based on augmented reality, this study measures functional suitability using the BlackBox testing method, wherein the black-box testing results test 8 functions and usability standards. reached $78.58 \%$ with good classification [13]. The next study is Functional Suitability Measurement using GoalOriented Approach based on ISO/IEC 25010 for Academics Information System. The result shows that the measurement using a goal-oriented approach becomes more objective and suitable to the need of used Academics Information System quality improvement for the institution than the measurement with ISO/IEC 25010 only [14]. The other study is, Usability Testing Using the Use Questionnaire in the Sipolin Application of West Java Province, This study focuses on how to test the user interface of SIPOLIN using Usability Testing with USE Questionnaire on SIPOLIN version 1.0. The result of this research shows all attributes have an average value above 3 that indicates SIPOLIN has a very good aspect of usability value [15]. Another related research is Analysis of the Quality of Information Systems for Monitoring Student Character Formation at Smk N 2 Depok Sleman, in this study analyzes the quality of the information system also measured from 2 characteristics namely functional suitability and usability. The results of this study are the information system has met ISO 25010 standards on functional suitability characteristics with a value of 1 (good), usability characteristics of $85.3 \%$ (very feasible) [3]. The other study is Analysis of the Quality of Information System for School Activities Based on Mobile Web in Public High School 2 Yogyakarta, where the goal of this study is to The purpose of this research is to guarantee the quality level of the School Activity Information System based on the mobile web so that errors do not occur as well as the features and functionality as promised by testing using the ISO 25010 standard. Where in this study 2 characteristics will be used, namely functional suitability and usability[16].

Based on the theory of several previous studies, this research will analyze the suitability of the sales order management information system functionality and the extent to which a system can be used by its users based on ISO 25010 characteristics, namely functional suitability and 
usability. And the purpose of this research is to determine the quality of the sales order management information system.

\section{RESEARCH METHOD}

In this research, to determine the quality of the sales order management information system, it is analyzed based on 2 characteristics of the ISO 25010 information system quality. The research starts from literature study and observation, then continues with analysis and report writing.

\section{A. Functional Suitability}

The functional suitability test aims to determine whether the system is running according to the scenario and produces outputs that match the reaction of a particular action. Testing is done using the BlackBox method, where this test is to match that the functions designed for each system have been running according to their respective goals [17]. Testing with the BlackBox method refers to previous studies that have previously been carried out, testing is carried out based on the functions available on the system which are then carried out with the validation step of the results of the function [16], [17], [18], which is divided into three sub-characteristics of functional suitability when the sub-characteristics are functional completeness which consists of 17 functions, functional correctness which consists of 6 functions and functional appropriateness which consists of 2 functions. A brief description of the sub-characteristics of functional suitability based on ISO 25010 is:

1. Functional Completeness

The extent to which the function set includes all defined user tasks and objectives.

2. Functional Correctness.

The extent to which the product or system provides correct results with the required level of precision.

3. Functional Apptopriateness

The extent to which the function facilitates the achievement of certain tasks and goals.

The assessment is based on the Guttman scale, which is a scale used for clear answers such as yes or no, true or false, positive-negative, agree and disagree [19]. The test results are then calculated using the feature completeness matrix [20] with the following equation 1.

$$
X=\frac{i}{p}(1)
$$

Where :

$\mathrm{P}=$ number of features designed

$\mathrm{i}=$ number of features implemented successfully

Values X closer to 1 indicate most of the proposed features were implemented [20]. 
INTENSIF, Vol.5 No.2 August 2021

ISSN: 2580-409X (Print) / 2549-6824 (Online)

DOI: https://doi.org/10.29407/intensif.v5i2.15537

The characteristics of respondents used in functional suitability are respondents who are directly involved in system development and also as users who have an understanding of information technology. So that in this test 5 respondents were determined to represent each division that uses the sales order management information system and who are directly involved in system development. The respondents are supervisors from each division who will use information systems with an IT background and have experience in using information systems on average for the last 4 years at PT. Baliyoni Saguna.

Table 1. FUNCTIONAL COMPLETENESS FORM

\begin{tabular}{|c|c|c|c|c|}
\hline $\begin{array}{l}\text { Number of } \\
\text { Function }\end{array}$ & Function & Expected Results & $\begin{array}{c}\text { As } \\
\text { Expected }\end{array}$ & $\begin{array}{c}\text { Not As } \\
\text { Expected }\end{array}$ \\
\hline \multicolumn{5}{|l|}{ Administrator } \\
\hline 1 & $\begin{array}{l}\text { Login as } \\
\text { Administrator }\end{array}$ & $\begin{array}{l}\text { The login function as administrator is } \\
\text { running correctly. }\end{array}$ & & \\
\hline 2 & $\begin{array}{l}\text { Adding new user } \\
\text { data }\end{array}$ & $\begin{array}{l}\text { The add new user function is running } \\
\text { correctly }\end{array}$ & & \\
\hline 3 & Delete user & $\begin{array}{l}\text { The user delete function is running } \\
\text { correctly }\end{array}$ & & \\
\hline \multicolumn{5}{|l|}{ Marketing } \\
\hline 4 & $\begin{array}{l}\text { Login as } \\
\text { Marketing }\end{array}$ & $\begin{array}{l}\text { The login function as marketing is } \\
\text { running correctly. }\end{array}$ & & \\
\hline 5 & $\begin{array}{l}\text { Add sales order } \\
\text { data }\end{array}$ & $\begin{array}{l}\text { The new add sales order function is } \\
\text { running correctly }\end{array}$ & & \\
\hline 6 & $\begin{array}{l}\text { Update sales } \\
\text { order data }\end{array}$ & $\begin{array}{l}\text { Sales order data update function is } \\
\text { running correctly }\end{array}$ & & \\
\hline \multicolumn{5}{|l|}{ Sales Admin } \\
\hline 7 & $\begin{array}{l}\text { Login as Sales } \\
\text { Admin }\end{array}$ & $\begin{array}{l}\text { The login function as a sales admin is } \\
\text { running correctly }\end{array}$ & & \\
\hline 8 & $\begin{array}{l}\text { Change the status } \\
\text { of the sales order } \\
\text { to " delivery } \\
\text { order" }\end{array}$ & $\begin{array}{l}\text { The function of changing the sales } \\
\text { order status to "delivery order" is } \\
\text { running correctly }\end{array}$ & & \\
\hline 9 & $\begin{array}{l}\text { Change sales } \\
\text { order status to } \\
\text { "ready to ship" }\end{array}$ & $\begin{array}{l}\text { The function of changing the sales } \\
\text { order status to "ready to ship" is } \\
\text { running correctly }\end{array}$ & & \\
\hline 10 & $\begin{array}{l}\text { Input the } \\
\text { delivery order } \\
\text { number }\end{array}$ & $\begin{array}{l}\text { The function of input the delivery order } \\
\text { is running correctly }\end{array}$ & & \\
\hline
\end{tabular}


INTENSIF, Vol.5 No.2 August 2021

ISSN: 2580-409X (Print) / 2549-6824 (Online)

DOI: https://doi.org/10.29407/intensif.v5i2.15537

Table 1. FunCtional COMPLETENESS Form [CONTINUE]

\begin{tabular}{|c|c|c|c|c|}
\hline $\begin{array}{l}\text { Number of } \\
\text { Function }\end{array}$ & Function & Expected Results & $\begin{array}{c}\text { As } \\
\text { Expected }\end{array}$ & $\begin{array}{c}\text { Not As } \\
\text { Expected }\end{array}$ \\
\hline \multicolumn{5}{|l|}{ Warehouse } \\
\hline 11 & $\begin{array}{l}\text { Login as } \\
\text { warehouse }\end{array}$ & $\begin{array}{l}\text { The login function as the warehouse is } \\
\text { running correctly }\end{array}$ & & \\
\hline 12 & $\begin{array}{l}\text { Change sales } \\
\text { order status to } \\
\text { "Prepared Items" }\end{array}$ & $\begin{array}{l}\text { The function of changing the sales } \\
\text { order status to "Prepared Items" is } \\
\text { running correctly }\end{array}$ & & \\
\hline 13 & $\begin{array}{l}\text { Change sales } \\
\text { order status to } \\
\text { "Items Ready" }\end{array}$ & $\begin{array}{l}\text { The function of changing the sales } \\
\text { order status to "Items Ready" is } \\
\text { running correctly }\end{array}$ & & \\
\hline \multicolumn{5}{|l|}{ Shipment } \\
\hline 14 & $\begin{array}{l}\text { Log in as a } \\
\text { shipping division }\end{array}$ & $\begin{array}{l}\text { the login function as a shipping } \\
\text { division is running correctly }\end{array}$ & & \\
\hline 15 & $\begin{array}{l}\text { Change sales } \\
\text { order status to } \\
\text { "Delivered" }\end{array}$ & $\begin{array}{l}\text { The function of changing the sales } \\
\text { order status to " Delivered " is running } \\
\text { correctly }\end{array}$ & & \\
\hline \multicolumn{5}{|l|}{ General } \\
\hline 16 & $\begin{array}{l}\text { View sales order } \\
\text { details }\end{array}$ & $\begin{array}{l}\text { The sales order detail view function is } \\
\text { running correctly }\end{array}$ & & \\
\hline 17 & Logout & $\begin{array}{l}\text { The logout function is running } \\
\text { correctly }\end{array}$ & & \\
\hline
\end{tabular}

Table 2. FUNCTIONAL CORRECTNESS FORM

\begin{tabular}{|c|c|c|c|c|}
\hline $\begin{array}{c}\text { Number } \\
\text { of } \\
\text { Function }\end{array}$ & Function & Expected Results & $\begin{array}{c}\text { As } \\
\text { Expected }\end{array}$ & $\begin{array}{c}\text { Not As } \\
\text { Expected }\end{array}$ \\
\hline 1 & $\begin{array}{l}\text { Identify username and } \\
\text { password }\end{array}$ & $\begin{array}{l}\text { The login process to the system } \\
\text { according to the username and } \\
\text { password is running correctly }\end{array}$ & & \\
\hline 2 & $\begin{array}{l}\text { Calculation of the } \\
\text { amount of sales order } \\
\text { data on the dashboard }\end{array}$ & $\begin{array}{l}\text { Displays the exact amount of sales } \\
\text { order data that exists }\end{array}$ & & \\
\hline 3 & $\begin{array}{l}\text { Displays sales order } \\
\text { data based on sales } \\
\text { order date }\end{array}$ & $\begin{array}{l}\text { Process sales order data filter based } \\
\text { on sales order date }\end{array}$ & & \\
\hline 4 & $\begin{array}{l}\text { Displays sales data } \\
\text { based on customer } \\
\text { agencies }\end{array}$ & $\begin{array}{l}\text { Process sales order data filter based } \\
\text { on customer agencies }\end{array}$ & & \\
\hline 5 & $\begin{array}{l}\text { Displays sales data } \\
\text { based on Marketing } \\
\text { Name }\end{array}$ & $\begin{array}{l}\text { The process of filtering sales order } \\
\text { data is based on the name of the } \\
\text { marketing that created the sales order }\end{array}$ & & \\
\hline 6 & $\begin{array}{l}\text { Displays sales order } \\
\text { data based on the status } \\
\text { of the sales order }\end{array}$ & $\begin{array}{l}\text { Process sales order data filter based } \\
\text { on the status of the sales order }\end{array}$ & & \\
\hline
\end{tabular}

INTENSIF: Jurnal Ilmiah Penelitian dan Penerapan Teknologi Sistem Informasi 
INTENSIF, Vol.5 No.2 August 2021

ISSN: 2580-409X (Print) / 2549-6824 (Online)

DOI: https://doi.org/10.29407/intensif.v5i2.15537

Table 3. FUNCTIONAL APPROPTIATENESS FORM

\begin{tabular}{cllcc}
\hline \hline $\begin{array}{c}\text { Number of } \\
\text { Function }\end{array}$ & Function & \multicolumn{1}{c}{ Expected Results } & $\begin{array}{c}\text { As } \\
\text { Expected }\end{array}$ & $\begin{array}{c}\text { Not As } \\
\text { Expected }\end{array}$ \\
\hline 1 & Upload sales & Successfully uploaded the sales & & \\
& order & order document & \\
& documents & & \\
\hline 2 & Download & Successfully download the sales & \\
& sales order & order document & \\
& documents & & \\
\end{tabular}

B. Usability

Usability is a factor that judges from the point of view of the ease with which software is used and studied [21]. Usability refers to the quality of the user's experience such as effectiveness, efficiency, and the overall satisfaction of the user when interacting with the systems [22]. Usability tests aim to determine the extent to which the system can be used by users to achieve goals effectively, efficiently, and with satisfaction in the user's context. Tests were carried out by using a questionnaire that was prepared based on usability criteria, namely, usefulness, ease of use, ease of learning, and satisfaction compiled based on the Use Questionnaire by Arnold M. Lund (2001)[23].

Table 4. FUnCTIONAL USABILITY FORM

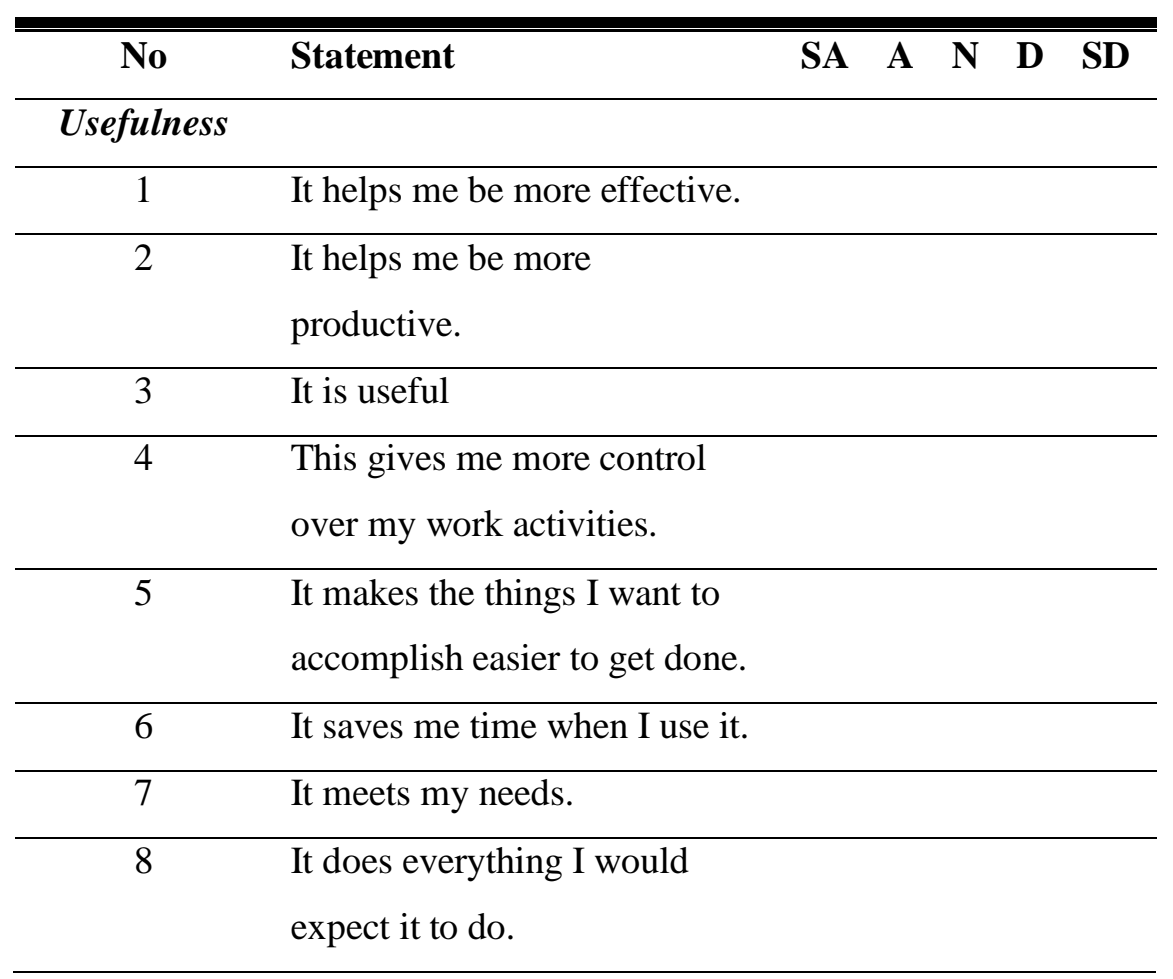


INTENSIF, Vol.5 No.2 August 2021

ISSN: 2580-409X (Print) / 2549-6824 (Online)

DOI: https://doi.org/10.29407/intensif.v5i2.15537

Usability testing was carried out using a Likert scale [24] with 5 response points, 5 points for strongly agree, 4 points for agreeing, 3 points for neutral, 2 for points disagree, and 1 point for strongly disagree. Skor untuk usability dihitung dengan persamaan 2 dan 3 berikut.

$$
\begin{gathered}
\text { Total Score }=(S A \times 5)+(A \times 4)+(N \times 3)+(D \times 2)+(S D \times 1)(2) \\
\text { Pscore }=\left(\frac{\text { Total Score }}{(\text { ix rx 5 })}\right) \times 100 \%(3)
\end{gathered}
$$

Where :

$\mathrm{i}=$ number of statements

$\mathrm{r}=$ number of respondents

Table 5. USABILITY SCORE INTERPRETATION

\begin{tabular}{ccc}
\hline \hline No & Percentage & Interpretation \\
\hline 1 & $0 \%-20 \%$ & Very unworthy \\
\hline 2 & $21 \%-40 \%$ & Less Feasible \\
\hline 3 & $41 \%-60 \%$ & Decent Enough \\
\hline 4 & $61 \%-80 \%$ & Feasible \\
\hline 5 & $80 \%-100 \%$ & Very Feasible \\
\hline
\end{tabular}

Usability testing was carried out through a questionnaire prepared based on usability criteria with a total of 30 statements [23]. And respondents in usability testing are all users of the sales order management information system from the marketing, sales admin, warehouse, and shipping divisions so that the total number of respondents was 17 respondents.

\section{RESULT AND DISCUSSION}

\section{A. Functional Suitability}

The results of the functional suitability test using a questionnaire prepared based on system requirements and the BlackBox testing method and calculated using a functional matrix using equation 1 are described in the following explanation.

1. Functional Completeness

In the functional completeness test, 17 functions tested based on the Guttman scale with 5 respondents, shows that every function in the system already has the appropriate output when validation is carried out. The indicators of the tests carried out are shown in Table 6 which is the result of the recapitulation of one of the respondents who shows that the existing functions in the system are in accordance with the expected output. 
INTENSIF, Vol.5 No.2 August 2021

ISSN: 2580-409X (Print) / 2549-6824 (Online)

DOI: https://doi.org/10.29407/intensif.v5i2.15537

Table 6. RECAPITULATION OF ONE OF THE RESPONDENTS

\begin{tabular}{|c|c|c|c|c|}
\hline $\begin{array}{l}\text { Number of } \\
\text { Function }\end{array}$ & Function & Expected Results & $\begin{array}{c}\text { As } \\
\text { Expected }\end{array}$ & $\begin{array}{c}\text { Not As } \\
\text { Expected }\end{array}$ \\
\hline \multicolumn{5}{|l|}{ Administrator } \\
\hline 1 & $\begin{array}{l}\text { Login as } \\
\text { Administrator }\end{array}$ & $\begin{array}{l}\text { The login function as administrator } \\
\text { is running correctly. }\end{array}$ & $\sqrt{ }$ & \\
\hline 2 & $\begin{array}{l}\text { Adding new } \\
\text { user data }\end{array}$ & $\begin{array}{l}\text { The add new user function is } \\
\text { running correctly }\end{array}$ & $\sqrt{ }$ & \\
\hline 3 & Delete user & $\begin{array}{l}\text { The user delete function is running } \\
\text { correctly }\end{array}$ & $\sqrt{ }$ & \\
\hline \multicolumn{5}{|l|}{ Marketing } \\
\hline 4 & $\begin{array}{l}\text { Login as } \\
\text { Marketing }\end{array}$ & $\begin{array}{l}\text { The login function as marketing is } \\
\text { running correctly. }\end{array}$ & $\sqrt{ }$ & \\
\hline 5 & $\begin{array}{l}\text { Add sales } \\
\text { order data }\end{array}$ & $\begin{array}{l}\text { The new add sales order function is } \\
\text { running correctly }\end{array}$ & $\sqrt{ }$ & \\
\hline 6 & $\begin{array}{l}\text { Update sales } \\
\text { order data }\end{array}$ & $\begin{array}{l}\text { Sales order data update function is } \\
\text { running correctly }\end{array}$ & $\sqrt{ }$ & \\
\hline$\ldots$ & $\cdots$ & $\cdots$ & $\ldots$ & $\ldots$ \\
\hline
\end{tabular}

Then based on these results, a functional matrix calculation can be performed using equation 1 as follows.

$$
\begin{aligned}
X=\frac{i}{P} & =\frac{17 \times 5}{17 \times 5} \\
X & =1
\end{aligned}
$$

The calculation of the functional matrix shows the value of $X=1$, which means that the Functional Completeness indicator of all functions in the system has been running as expected. Or in other words the entire function runs by producing the appropriate output.

2. Functional Correctness

In testing functional correctness, 6 features were tested with the BlackBox testing method. Of the 5 respondents overall answered that all the features were running as expected. Table 7 bellow, show the recapitulation of one of the respondents who shows that the existing functions in the system are following the expected output. 
INTENSIF, Vol.5 No.2 August 2021

ISSN: 2580-409X (Print) / 2549-6824 (Online)

DOI: https://doi.org/10.29407/intensif.v5i2.15537

Table 7. RECAPITULATION OF ONE OF THE RESPONDENTS

\begin{tabular}{cllcc}
\hline $\begin{array}{c}\text { Number of } \\
\text { Function }\end{array}$ & Function & \multicolumn{1}{c}{ Expected Results } & $\begin{array}{c}\text { As } \\
\text { Expected }\end{array}$ & $\begin{array}{c}\text { Not As } \\
\text { Expected }\end{array}$ \\
\hline 1 & $\begin{array}{l}\text { Identify } \\
\text { username and } \\
\text { password }\end{array}$ & $\begin{array}{l}\text { The login process to the system } \\
\text { according to the username and } \\
\text { password is running correctly }\end{array}$ & $\sqrt{ }$ & \\
\hline 2 & $\begin{array}{l}\text { Calculation } \\
\text { of the amount } \\
\text { of sales order } \\
\text { data on the } \\
\text { dashboard }\end{array}$ & $\begin{array}{l}\text { Displays the exact amount of } \\
\text { sales order data that exists }\end{array}$ & $\sqrt{ }$ & \\
\hline 3 & $\begin{array}{l}\text { Displays } \\
\text { sales order } \\
\text { data based on } \\
\text { sales order } \\
\text { date }\end{array}$ & based on sales order date & $\sqrt{ }$ & \\
\hline$\ldots$ & $\ldots$ & $\ldots$ & $\ldots$ & $\ldots$ \\
\hline
\end{tabular}

From these results indicate that the features tested using BlackBox testing indicate that the features of the information system provide appropriate and accurate output in line with the needs of its users. From these results, it can also be calculated the value of the functional matrix using equation 1 as follows.

$$
\begin{aligned}
& X=\frac{i}{P}=\frac{6 \times 5}{6 \times 5} \\
& X=1
\end{aligned}
$$

This result also shows the value of $X=1$, which means that the Functional Correctness of the validated indicators in the information system has succeeded in carrying out its functions accurately and in accordance with the purpose of the function.

3. Functional Appropriateness

Furthermore, functional appropriateness testing aims to see the extent to which the existing functions in the information system facilitate users in achieving certain tasks. Where in this test there are 2 functions that are tested in accordance with Table 3 . And the results of the recapitulation of test results from one of the respondents are shown in table 8 below. 
INTENSIF, Vol.5 No.2 August 2021

ISSN: 2580-409X (Print) / 2549-6824 (Online)

DOI: https://doi.org/10.29407/intensif.v5i2.15537

Table 8. ReCAPITUlation of ONE OF THE RESPONDENTS

\begin{tabular}{cllcc}
\hline $\begin{array}{c}\text { Number of } \\
\text { Function }\end{array}$ & Function & \multicolumn{1}{c}{ Expected Results } & $\begin{array}{c}\text { As } \\
\text { Expected }\end{array}$ & $\begin{array}{c}\text { Not As } \\
\text { Expected }\end{array}$ \\
\hline 1 & $\begin{array}{l}\text { Upload sales } \\
\text { order } \\
\text { documents }\end{array}$ & $\begin{array}{l}\text { Successfully uploaded the sales } \\
\text { order document }\end{array}$ & $\sqrt{ }$ & \\
\hline 2 & $\begin{array}{l}\text { Download } \\
\text { sales order } \\
\text { documents }\end{array}$ & $\begin{array}{l}\text { Successfully download the sales } \\
\text { order document }\end{array}$ & $\sqrt{ }$ \\
& & & \\
\hline
\end{tabular}

Based on the results of tests conducted on Tabel 8, with the same number of respondents and the same method, it shows that the value of $X=1$, which means that all functions on the Functional Appropriateness indicator have been running according to the purpose of the function, and the calculation of the functional matrix with equation 1 is as follows.

$$
\begin{aligned}
& X=\frac{i}{P}=\frac{2 \times 5}{2 \times 5} \\
& X=1
\end{aligned}
$$

The overall results of testing on the functional suitability are shown in table 9 below.

Table 9. Functional Suitability TeSt Results

\begin{tabular}{lc}
\hline Sub-Characteristics of Functional Suitability & X value \\
\hline Functional Completeness & 1 \\
\hline Functional Correctness & 1 \\
\hline Functional Appropriateness & 1 \\
\hline Rata-rata & 1 \\
\hline
\end{tabular}

From the results of the functional suitability test, it can be said that the sales order management system has met the functional quality standards, where all the functions designed are following the functions realized in the system, this is shown from the results of the functional matrix calculation, the average value of $X=1$ [20].

\section{B. Usability}

The usability test was conducted using a Use Questionnaire with a total of 30 questions which were measured using a linkert scale. The number of respondents on usability was 17 respondents. Testing is based on usability criteria, namely usefulness, ease of use, ease of learning, and satisfaction. The results of usability testing can be seen in Figure 1 Below. 
INTENSIF, Vol.5 No.2 August 2021

ISSN: 2580-409X (Print) / 2549-6824 (Online)

DOI: https://doi.org/10.29407/intensif.v5i2.15537

\begin{tabular}{|c|c|c|c|c|c|c|c|c|c|c|c|c|c|c|c|c|c|c|c|c|c|c|c|c|c|c|c|c|c|c|c|c|}
\hline \multirow{3}{*}{ Respondents } & \multicolumn{30}{|c|}{ Statement } & \multirow{3}{*}{ Total Score } & \multirow{3}{*}{ Max Score } \\
\hline & \multicolumn{8}{|c|}{ Usefullness } & \multicolumn{11}{|c|}{ Ease of Use } & \multicolumn{4}{|c|}{ Easy of Learning } & \multicolumn{7}{|c|}{ Statisfaction } & & \\
\hline & \begin{tabular}{|l|}
1 \\
\end{tabular} & 2 & 3 & 4 & 5 & 6 & 7 & 8 & 9 & 10 & 11 & 12 & 13 & 14 & 15 & 16 & \begin{tabular}{l|l}
17 & 1 \\
\end{tabular} & \begin{tabular}{l|l}
18 & 1 \\
\end{tabular} & \begin{tabular}{l|l}
19 & 2 \\
\end{tabular} & \begin{tabular}{l|l}
20 & 2 \\
\end{tabular} & \begin{tabular}{l|l}
21 & 2 \\
\end{tabular} & \begin{tabular}{l|l}
22 & 2 \\
\end{tabular} & \begin{tabular}{l|l}
23 & 2 \\
\end{tabular} & \begin{tabular}{l|l}
24 & 2 \\
\end{tabular} & \begin{tabular}{l|l}
25 & 2 \\
\end{tabular} & \begin{tabular}{l|l}
26 & 2 \\
\end{tabular} & \begin{tabular}{|l|l|}
27 & 2 \\
\end{tabular} & \begin{tabular}{l|l}
28 & 2 \\
\end{tabular} & 29 & 30 & & \\
\hline 1 & 3 & 4 & 4 & 5 & 5 & 4 & 5 & 5 & 4 & 3 & 5 & 5 & 5 & 5 & 5 & 4 & 5 & \begin{tabular}{l|l}
5 & 5 \\
\end{tabular} & 5 & \begin{tabular}{l|l}
4 & 2 \\
\end{tabular} & 4 & 4 & 4 & 3 & 5 & 4 & 5 & 5 & 4 & 5 & 133 & 150 \\
\hline 2 & 4 & 5 & 4 & 3 & 5 & 5 & 4 & 5 & 3 & 4 & 5 & 3 & 4 & 5 & 4 & 5 & 4 & \begin{tabular}{l|l}
5 & 5 \\
\end{tabular} & 5 & \begin{tabular}{l|l}
4 & 5 \\
\end{tabular} & 5 & 5 & 3 & 5 & \begin{tabular}{l|l}
3 & 2 \\
\end{tabular} & 4 & 5 & 5 & 3 & 4 & 128 & 150 \\
\hline 3 & 5 & 4 & 4 & 5 & 4 & 5 & 3 & 4 & 4 & 3 & 5 & 4 & 5 & 4 & 5 & 5 & 5 & 5 & 5 & \begin{tabular}{l|l}
5 & 2 \\
\end{tabular} & 4 & 5 & 4 & 4 & \begin{tabular}{l|l}
5 & 2 \\
\end{tabular} & 4 & 4 & 5 & 5 & 5 & 134 & 150 \\
\hline 4 & 3 & 4 & 3 & 5 & 5 & 4 & 4 & 4 & 4 & 5 & 5 & 5 & 4 & 5 & 5 & 5 & \begin{tabular}{l|l}
3 \\
\end{tabular} & \begin{tabular}{l|l}
45 \\
\end{tabular} & 5 & \begin{tabular}{l|l}
3 & 4 \\
\end{tabular} & 4 & 4 & 5 & 4 & 55 & 5 & 5 & 4 & 5 & \begin{tabular}{l|l}
4 \\
\end{tabular} & 130 & 150 \\
\hline 5 & 4 & 4 & 5 & 5 & 3 & 5 & 4 & 3 & 4 & 5 & 4 & 5 & 3 & 3 & 5 & 5 & \begin{tabular}{l|l}
5 & \\
\end{tabular} & 45 & \begin{tabular}{l|l}
5 & 2 \\
\end{tabular} & \begin{tabular}{l|l}
45 & 5 \\
\end{tabular} & 5 & 5 & 5 & 3 & 53 & 3 & 3 & 4 & 4 & 5 & 127 & 150 \\
\hline 6 & 4 & 4 & 5 & 5 & 4 & 44 & 5 & 5 & 3 & \begin{tabular}{|l|}
4 \\
\end{tabular} & 5 & 5 & 44 & 5 & 5 & 4 & $\begin{array}{ll}4 \\
\end{array}$ & \begin{tabular}{l|l}
3 & \\
\end{tabular} & \begin{tabular}{l|l}
43 \\
\end{tabular} & \begin{tabular}{l|l}
3 & 4 \\
\end{tabular} & 4 & 3 & 5 & 3 & \begin{tabular}{l|l}
45 \\
\end{tabular} & 5 & \begin{tabular}{|l|}
4 \\
\end{tabular} & 5 & 4 & \begin{tabular}{|l|}
4 \\
\end{tabular} & 126 & 150 \\
\hline 7 & 5 & 5 & 3 & 5 & 5 & 4 & 5 & 5 & 4 & 5 & 4 & 3 & 3 & 4 & 5 & 3 & $5 \mid$ & \begin{tabular}{l|l}
4 & 2 \\
\end{tabular} & 4 & 5 & 5 & 4 & 5 & 5 & 53 & 3 & 5 & 4 & 3 & 5 & 130 & 150 \\
\hline 8 & 3 & 4 & 4 & 3 & 4 & 3 & 4 & 5 & 3 & 5 & 4 & 4 & 4 & 3 & 5 & 4 & \begin{tabular}{l|l}
4 & \\
\end{tabular} & \begin{tabular}{l|l}
4 & \\
\end{tabular} & \begin{tabular}{l|l}
4 \\
\end{tabular} & \begin{tabular}{l|l}
3 & 4 \\
\end{tabular} & 4 & 4 & 5 & 4 & 45 & 5 & 3 & 5 & 5 & 3 & 119 & 150 \\
\hline 9 & 4 & 3 & 4 & \begin{tabular}{|l|}
3 \\
\end{tabular} & 5 & 5 & 3 & 5 & 3 & 44 & 4 & 5 & 5 & 5 & \begin{tabular}{|l|}
4 \\
\end{tabular} & 5 & \begin{tabular}{l|l}
5 & \\
\end{tabular} & \begin{tabular}{l|l}
4 & 3 \\
\end{tabular} & 3 & \begin{tabular}{l|l}
5 & 4 \\
\end{tabular} & 4 & 3 & 4 & 4 & \begin{tabular}{l|l}
5 & 5 \\
\end{tabular} & 5 & \begin{tabular}{|l|}
4 \\
\end{tabular} & 3 & 3 & \begin{tabular}{l|l}
3 & \\
\end{tabular} & 122 & 150 \\
\hline 10 & 5 & 4 & 5 & 4 & 5 & 5 & 5 & 4 & 5 & 3 & 5 & 3 & 5 & 4 & \begin{tabular}{l|l}
4 \\
\end{tabular} & 5 & 5 & \begin{tabular}{l|l}
3 & 2 \\
\end{tabular} & \begin{tabular}{l|l}
4 & \\
\end{tabular} & \begin{tabular}{l|l}
4 & 3 \\
\end{tabular} & 3 & 4 & 4 & 3 & \begin{tabular}{l|l}
45 & \\
\end{tabular} & 5 & 3 & 5 & 5 & 4 & 127 & 150 \\
\hline 11 & 3 & 3 & 5 & 5 & 3 & 4 & 4 & 3 & 4 & 3 & 5 & 5 & 4 & 5 & 3 & 5 & 5 & 35 & 5 & 55 & 5 & 5 & 3 & 3 & 53 & 3 & 3 & 4 & 5 & 5 & 123 & 150 \\
\hline 12 & 4 & 4 & 5 & 5 & 5 & 5 & 5 & 5 & 4 & 5 & 4 & 5 & 3 & 5 & 5 & 5 & \begin{tabular}{l|l}
5 & \\
\end{tabular} & \begin{tabular}{l|l}
4 & \\
\end{tabular} & \begin{tabular}{l|l}
4 & \\
\end{tabular} & \begin{tabular}{l|l}
4 & 5 \\
\end{tabular} & 5 & 4 & 4 & \begin{tabular}{l|l}
4 & \\
\end{tabular} & \begin{tabular}{l|l}
5 & 3 \\
\end{tabular} & 3 & 5 & 4 & 5 & \begin{tabular}{l|l}
4 \\
\end{tabular} & 134 & 150 \\
\hline 13 & 3 & 3 & 4 & 5 & 5 & 44 & 44 & 5 & 5 & 44 & 5 & 4 & 5 & 4 & \begin{tabular}{|l|l|}
3 \\
\end{tabular} & 5 & 5 & \begin{tabular}{l|l}
5 & \\
\end{tabular} & 45 & \begin{tabular}{l|l}
5 & 4 \\
\end{tabular} & 4 & 5 & 3 & 5 & \begin{tabular}{l|l}
5 & 5 \\
\end{tabular} & 5 & \begin{tabular}{|l|}
4 \\
\end{tabular} & 5 & 4 & 5 & 132 & 150 \\
\hline 14 & 5 & 5 & 4 & 5 & 4 & 3 & 5 & 4 & 5 & 5 & 5 & 5 & 4 & 5 & \begin{tabular}{l|l}
4 \\
\end{tabular} & 5 & \begin{tabular}{l|l}
4 \\
\end{tabular} & \begin{tabular}{l|l}
5 & 3 \\
\end{tabular} & \begin{tabular}{l|l}
3 & \\
\end{tabular} & \begin{tabular}{l|l}
4 & 4 \\
\end{tabular} & 4 & 3 & 4 & 5 & \begin{tabular}{l|l}
5 & 5 \\
\end{tabular} & 5 & 3 & 4 & 3 & 4 & 129 & 150 \\
\hline 15 & 5 & 4 & 5 & 5 & 4 & 4 & 3 & 5 & 5 & 4 & 5 & 3 & 5 & 3 & 5 & 5 & \begin{tabular}{l|l}
3 & \\
\end{tabular} & \begin{tabular}{l|l}
4 & 5 \\
\end{tabular} & 5 & \begin{tabular}{l|l}
3 & 5 \\
\end{tabular} & 5 & 4 & 4 & 5 & \begin{tabular}{l|l}
3 \\
\end{tabular} & 3 & 4 & 5 & 4 & 5 & 127 & 150 \\
\hline 16 & 3 & 5 & 4 & 4 & 5 & 4 & 4 & 4 & 4 & 5 & 5 & 5 & 4 & 5 & 4 & 5 & 4 & 5 & 5 & \begin{tabular}{l|l}
5 & 2 \\
\end{tabular} & 4 & 3 & 3 & 3 & \begin{tabular}{l|l}
4 & 5 \\
\end{tabular} & 5 & 4 & 5 & 3 & 4 & 127 & 150 \\
\hline \multirow[t]{2}{*}{17} & 4 & 5 & 3 & 4 & 5 & 5 & 4 & 5 & 5 & 5 & 3 & 5 & 4 & 5 & 4 & 3 & 5 & 5 & 4 & \begin{tabular}{l|l}
5 & 4 \\
\end{tabular} & 4 & 5 & 5 & 5 & 3 & 4 & 3 & 5 & 5 & 4 & 131 & 150 \\
\hline & 67 & 70 & 71 & 76 & 76 & 73 & 71 & 76 & 69 & 72 & 78 & 74 & 71 & 75 & 75 & 78 & \begin{tabular}{l|l}
76 & 7
\end{tabular} & \begin{tabular}{l|l}
72 & 7 \\
\end{tabular} & \begin{tabular}{l|l}
74 & 7 \\
\end{tabular} & \begin{tabular}{l|l}
71 & 7 \\
\end{tabular} & \begin{tabular}{l|l}
73 & 7 \\
\end{tabular} & 707 & \begin{tabular}{l|l|l}
70 & \\
\end{tabular} & \begin{tabular}{l|l}
68 & 7 \\
\end{tabular} & \begin{tabular}{l|l}
75 & 7 \\
\end{tabular} & $71 \epsilon$ & \begin{tabular}{l|l}
67 & 7 \\
\end{tabular} & \begin{tabular}{l|l}
77 & 7 \\
\end{tabular} & 70 & 73 & 2179 & 2550 \\
\hline
\end{tabular}

Figure 1. UsABILITY TEST RESUlT

From the usability measurement data, it can be seen that the overall score obtained is 2179 from the maximum score of 2550 . Then, when analyzed in more detail on each parameter measured in usability testing, it can be seen in the following graphic data.

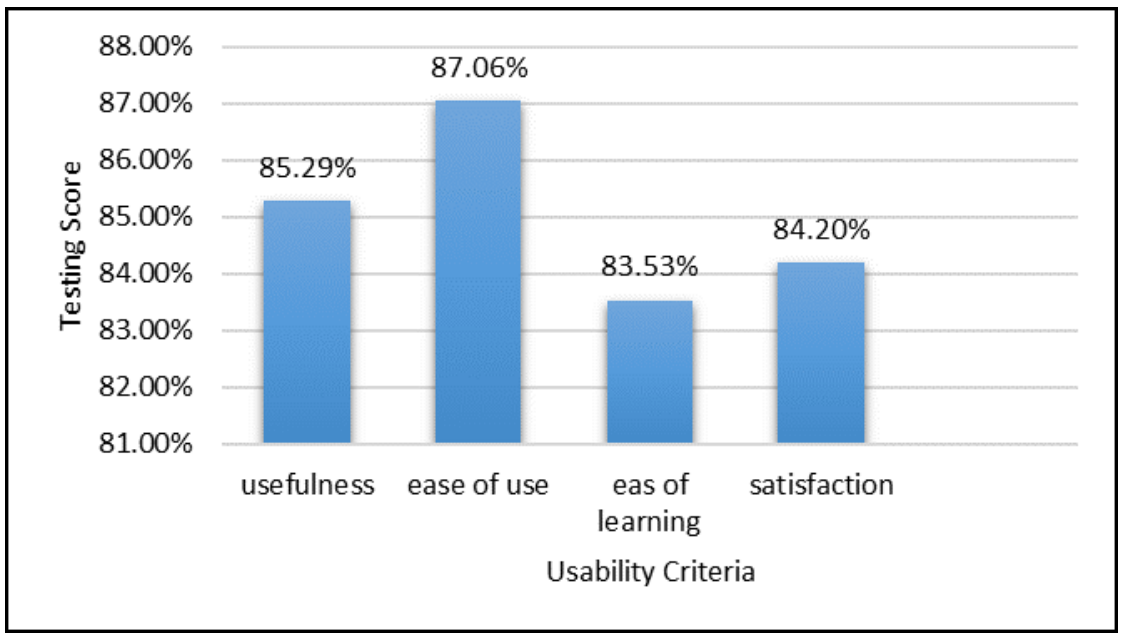

Figure 2. USABILITY MEASUREMENT CHART

From the graphic data in Figure 2, it is known that the sales management information system is perceived to have good use or the system is perceived to be very useful in supporting the work of its users with a usability value of $85.29 \%$. And the next parameter shows the information system has good ease of use, this is indicated by the measurement results on the ease of use parameter of $87.06 \%$. Then the next parameter shows that the information system has ease in learning or in other words new users will easily understand the use of the information system, this is indicated by the ease of learning value of $83.53 \%$. And users are satisfied with the existence of a sales management information system which is shown in the 
INTENSIF, Vol.5 No.2 August 2021

ISSN: 2580-409X (Print) / 2549-6824 (Online)

DOI: https://doi.org/10.29407/intensif.v5i2.15537

satisfaction parameter to obtain results of $84.20 \%$. Then for the overall score can be seen in Table 7 below.

Tabel 7. UsABILITY TEST RESUlTS

\begin{tabular}{cc}
\hline \hline Maximum Score & Total Test Score \\
\hline 2179 & 2550 \\
\hline $100 \%$ & $85.45 \%$ \\
\hline
\end{tabular}

From the results obtained usability from the sales order management information system obtained 2179 scores from a maximum score of 2550. These results indicate that the interpretation of the sales order management system usability score is at a score of $85.45 \%$. Where when compared with table 5, the sales order management information system is at a very feasible level to be implemented.

Based on the results of testing two quality characteristics of information systems based on ISO 25010, namely functional suitability and usability, the results indicate that the sales order management information system implemented at PT. Bali Yoni Saguna has met these two quality standards.

\section{CONCLUSION}

Based on the results of the research conducted, it can be concluded that the functional suitability and usability analysis to determine the quality of the sales order management system, can be concluded that the management system has met the quality standards of functional suitability and usability. Where functional suitability and usability are two characteristics of system quality from the ISO 25010 standard. This is shown from the results of the functional suitability where from each sub-characteristic the value of $X=1$ is obtained, which indicates that the system runs according to the scenario and produces output following the reaction of action determined. And the results of the usability test show that the sales order management system is at a score of $85.45 \%$, where the measurement results show that the system has excellent usability for users, is easy to operate, and the system is very easy to understand for new users, and users are satisfied with the sales order management system, so that the system is very feasible to implement. From the research results, it can also be concluded that the BASSO information system meets the Functional Suitability standard by meeting the standards for each indicator, namely Functional Completeness, Functional Correctness, and Functional Apptopriateness. And BASSO has been implemented properly because based on testing the Usability value of system users, BASSO meets the standards on indicators of usefulness, ease of use, ease of learning, and satisfaction from users. 
This research is limited to the analysis of two system quality characteristics of the ISO 25010 standard, namely functional suitability, and usability. It is suggested to develop research to try to determine the quality of information systems on other supporting characteristics such as reliability, performance, and supportability [10] or others characteristic that can be used.

\section{ACKNOWLEDGMENTS}

A big thank you to PT. Bali Yoni Saguna for permitting research of the application of the sales management information system to determine the quality of the management system used. Hopefully, this research can provide benefits for the continued use of the sales order management information system in the future.

\section{REFERENCES}

[1] I. P. A. Putra Yudha, M. Sudarma, and P. Arya Mertasana, "Perancangan Aplikasi Sistem Inventory Barang Menggunakan Barcode Scanner Berbasis Android," J. SPEKTRUM, vol. 4, no. 2, p. 72, 2018, doi: 10.24843/spektrum.2017.v04.i02.p10.

[2] H. Haslinda et al., "Evaluation of e-Book applications using ISO 25010," 2nd Int. Symp. Technol. Manag. Emerg. Technol. ISTMET 2015 - Proceeding, no. October 2017, pp. 114-118, 2015, doi: 10.1109/ISTMET.2015.7359012.

[3] H. Setiawan and H. Jati, "Analisis Kualitas Sistem Informasi Pantauan Pembentukan Karakter Siswa Di Smk N 2 Depok Sleman," Elinvo (Electronics, Informatics, Vocat. Educ., vol. 2, no. 1, pp. 102-109, 2017, doi: 10.21831/elinvo.v2i1.16427.

[4] K. Budiarta, A. Iskandar, and M. Sudarma, "Audit Information System Development using COBIT 5 Framework (case Study: STMIK STIKOM Bali) Komang," Int. J. Eng. Emerg. Technol., vol. 1, no. 1, pp. 1-5, 2016.

[5] P. A. Ariawan, I. S. Putra, and I. M. Sudarma, "Analysis of Enterprise Architecture Design Using TOGAF Framework: A Case Study at Archival Unit of Faculty of Agricultural Technology of Udayana University,” Int. J. Eng. Emerg. Technol., vol. 2, no. 2, pp. 52-57, 2017.

[6] R. Perwitasari, R. Afawani, and S. E. Anjarwani, "Penerapan Metode Rational Unified Process (RUP) Dalam Pengembangan Sistem Informasi Medical Check Up Pada Citra Medical Centre," J. Teknol. Informasi, Komputer, dan Apl. (JTIKA ), vol. 2, no. 1, pp. 76-88, 2020, doi: 10.29303/jtika.v2i1.85.

[7] J. P. Miguel, D. Mauricio, and G. Rodríguez, "A Review of Software Quality Models for the Evaluation of Software Products," Int. J. Softw. Eng. Appl., vol. 5, no. 6, pp. 31-53, 2014, doi: 10.5121/ijsea.2014.5603.

[8] O. Gordieiev, V. Kharchenko, N. Forminykh, and V. Skylar, "Evolution of software quality models in context of the standard ISO 25010," Adv. Intell. Syst. Comput., vol. 286, no. January, 2014, doi: 10.1007/978-3-319-07013-1.

[9] E. V Veenendaal, "The New Standard for Software Product Quality." Testing Experience: The Magazine for Professional Testers," 2014.

[10] S. Anugrah and A. E. Putra, "Analisis Kualitas ISO 25010 Aplikasi Artificial Intelligence Troubleshooting Komputer dengan FURPS," E-TECH, vol. 6, no. 2, 2018.

[11] M. Rodríguez, R. Oviedo, and M. Piattini, "Evaluation of Software Product Functional Suitability: A Case Study," Softw. Qual. Prof., vol. 18, no. 3, p. 18, 2016, [Online]. Available: www.asq.org. 
INTENSIF, Vol.5 No.2 August 2021

ISSN: 2580-409X (Print) / 2549-6824 (Online)

DOI: https://doi.org/10.29407/intensif.v5i2.15537

[12] S. Riihiaho, "Usability Testing," Wiley Handb. Hum. Comput. Interact. Set, vol. 1, pp. 255-275, 2017, doi: 10.1002/9781118976005.ch14.

[13] G. Feoh and R. P. Wiryadikara, "Pengujian Functional Suitability Pada Implementasi," pp. 203-212, 2019.

[14] A. S. Puspaningrum, S. Rochimah, and R. J. Akbar, "Functional Suitability Measurement using Goal-Oriented Approach based on ISO/IEC 25010 for Academics Information System,” J. Inf. Syst. Eng. Bus. Intell., vol. 3, no. 2, p. 68, 2017, doi: 10.20473/jisebi.3.2.68-74.

[15] R. Firmansyah, "Usability Testing Dengan Use Questionnaire Pada Aplikasi Sipolin Provinsi Jawa Barat," Swabumi, vol. 6, no. 1, pp. 1-7, 2018, doi: 10.31294/swabumi.v6i1.3310.

[16] T. A. Ghaffur and Nurkhamid, "Analisis Kualitas Sistem Informasi Kegiatan Sekolah Berbasis Mobile Web Di Smk Negeri 2 Yogyakarta," Elinvo (Electronics, Informatics, Vocat. Educ., vol. 2, no. 1, pp. 94-101, 2017, doi: 10.21831/elinvo.v2i1.16426.

[17] S. Nidhra and J. Dondeti, "Black Box and White Box Testing Techniques - A Literature Review," Int. J. Embed. Syst. Appl., vol. 2, no. 2, pp. 29-50, 2012, doi: 10.5121/ijesa.2012.2204.

[18] W. N. Cholifah, Y. Yulianingsih, and S. M. Sagita, "Pengujian Black Box Testing pada Aplikasi Action \& Strategy Berbasis Android dengan Teknologi Phonegap," STRING (Satuan Tulisan Ris. dan Inov. Teknol., vol. 3, no. 2, p. 206, 2018, doi: 10.30998/string.v3i2.3048.

[19] A. Yulianto, U. P. Jaya, and S. Baru, "Pengujian Psikometri Skala Guttman untuk Mengukur," vol. 18, no. 2009, pp. 38-48, 2020.

[20] A. Acharya and D. Sinha, "Assessing the Quality of M-Learning Systems using ISO/IEC 25010," Int. J. Adv. Comput. Res., vol. 3, no. 3, pp. 2277-7970, 2013, [Online]. Available: https://www.semanticscholar.org/paper/Assessing-the-Quality-of-MLearning-Systems-using-AcharyaSinha/354f2c5de187b8733c91531a00b2cdd3346005bd.

[21] A. Hidayati, E. Oktariza, F. Rosmaningsih, and S. A. Lathifah, "Analisa Kualitas Perangkat Lunak Sistem Informasi Akademik Menggunakan McCall," Multinetics, vol. 3, no. 1, p. 48, 2017, doi: 10.32722/multinetics.vol3.no.1.2017.pp.48-53.

[22] I. G. W. Darma, K. S. Utami, and M. Sudarma, "User Experience Analysis on SSO Portal," vol. 3, no. 2, pp. 2-6, 2018.

[23] A. M. Lund, "Measuring usability with the USE questionnaire," Usability interface, vol. 8, no. 2, pp. 3-6, 2001.

[24] W. Budiaji, "Skala Pengukuran dan Jumlah Respon Skala Likert (The Measurement Scale and The Number of Responses in Likert Scale)," Ilmu Pertan. dan Perikan., vol. 2, no. 2, pp. 127-133, 2013, [Online]. Available: http://umbidharma.org/jipp. 